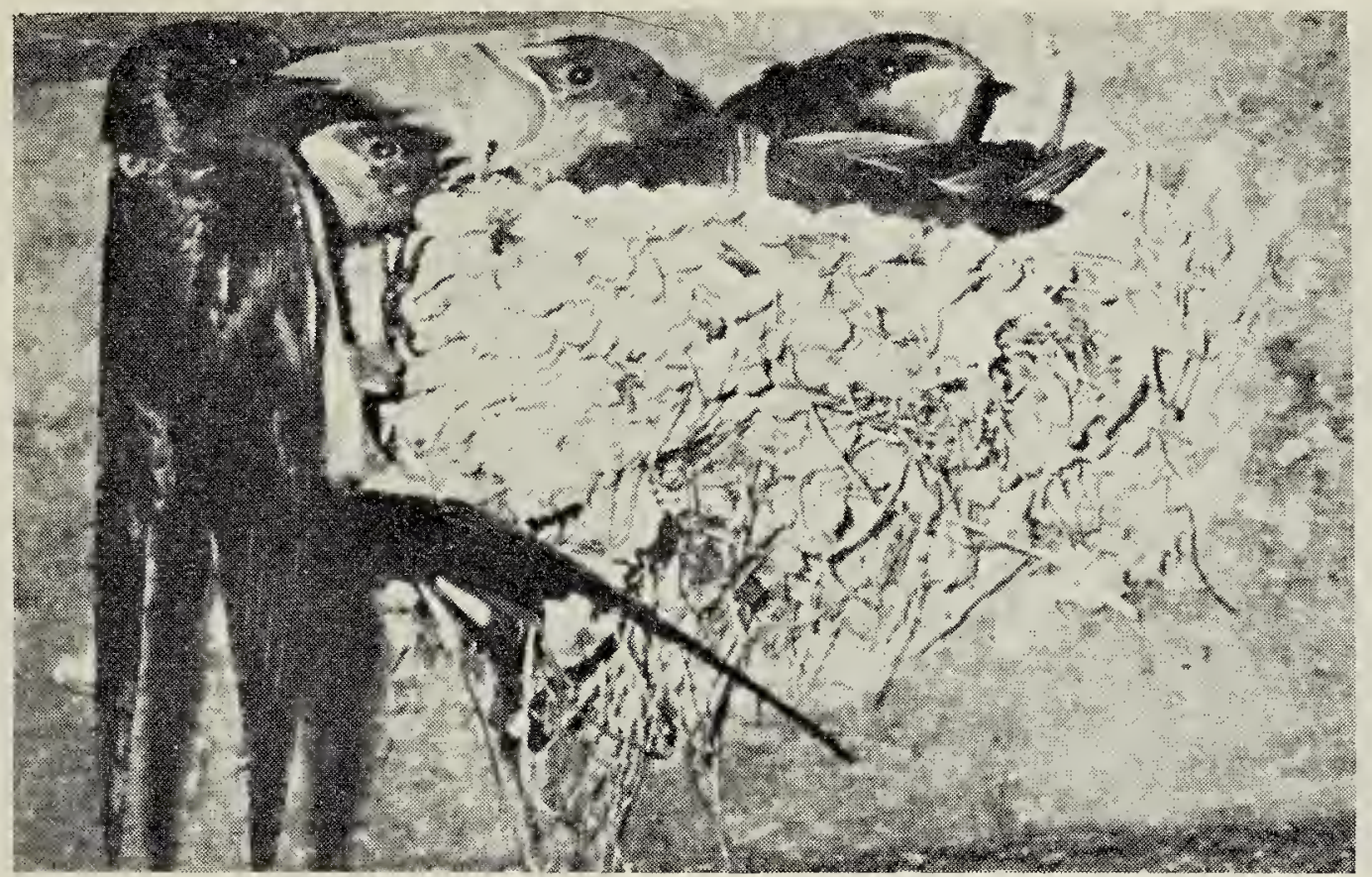

Photo by Don Dabbs, Saskatoon

Barn Swallow family at Emma Lake

\title{
ROAD KILLS OF BIRDS AND MAMMALS IN SOUTHEASTERN ALBERTA
}

by Kees Vermeer and Bruce Switzer, Canadian Wildlife Service, 10015 - 103 Avenue, Edmonton, Alberta

A survey of road kills of birds and mammals in southeastern Alberta was made incidental to other field studies for the Canadian Wildlife Service during May, June, July and August of 1967. The survey was conducted by car on paved roads only, between latitudes $49^{\circ} 00^{\prime} \mathrm{N}$ and $54^{\circ} 30^{\prime}$ $\mathrm{N}$ and longitudes $110^{\circ} 00^{\prime} \mathrm{W}$ and $114^{\circ} 00^{\prime} \mathrm{W}$.

The number of avian and mammalian road kills observed during 10,154 miles of driving is recorded in Table 1. Richardson's Ground Squirrels were most commonly found, making up 71 per cent of all observed road kills. None of the other species constituted more than five per cent of the kills.

The monthly variation of road kills of the Common Crow, Richardon's Ground Squirrel, Muskrat, and Striped Skunk observed per 1,000 miles driven in southeastern Alberta is shown in Table 2. Those four species were most commonly found, with at least 50 kills being observed for each. The large number of road kills of Richardson's Ground Squirrels in July is probably related to the greater number of animals present at that time as well as the increased highway traffic. The large kill of crows in July can be explained by the presence of young crows and by the occurrence on roads of many dead Richardson's Ground Squirrels which the crows feed upon. Muskrats wander extensively in the spring (Paul Errington, 1963. Muskrat populations. Iowa State University Press, 665 pp.), hence the large kill of that species in May. Many young Striped Skunks were observed as vehicle casualties in July and contributed to the increase in road kills of skunks during that month.

Table 2. Number of road kills observed for four species per $\mathbf{1 , 0 0 0}$ miles driven in southeastern Alberta during May, June, July and August, 1967.

Number of road kills per

Species $\quad 1000$ miles driven

Common Crow... $00 \underset{1}{24}{ }_{12}$

Richardson's

Ground

Squirrel $\ldots \ldots \ldots . \ldots 42 \quad 169 \quad 323 \quad 68$

$\begin{array}{lrrr}\text { Muskrat ….......... } 12 & 12 & 2 & 5\end{array}$

$\begin{array}{lllll}\text { Striped Skunk .... } & 4 & 4 & 9 & 6\end{array}$ 


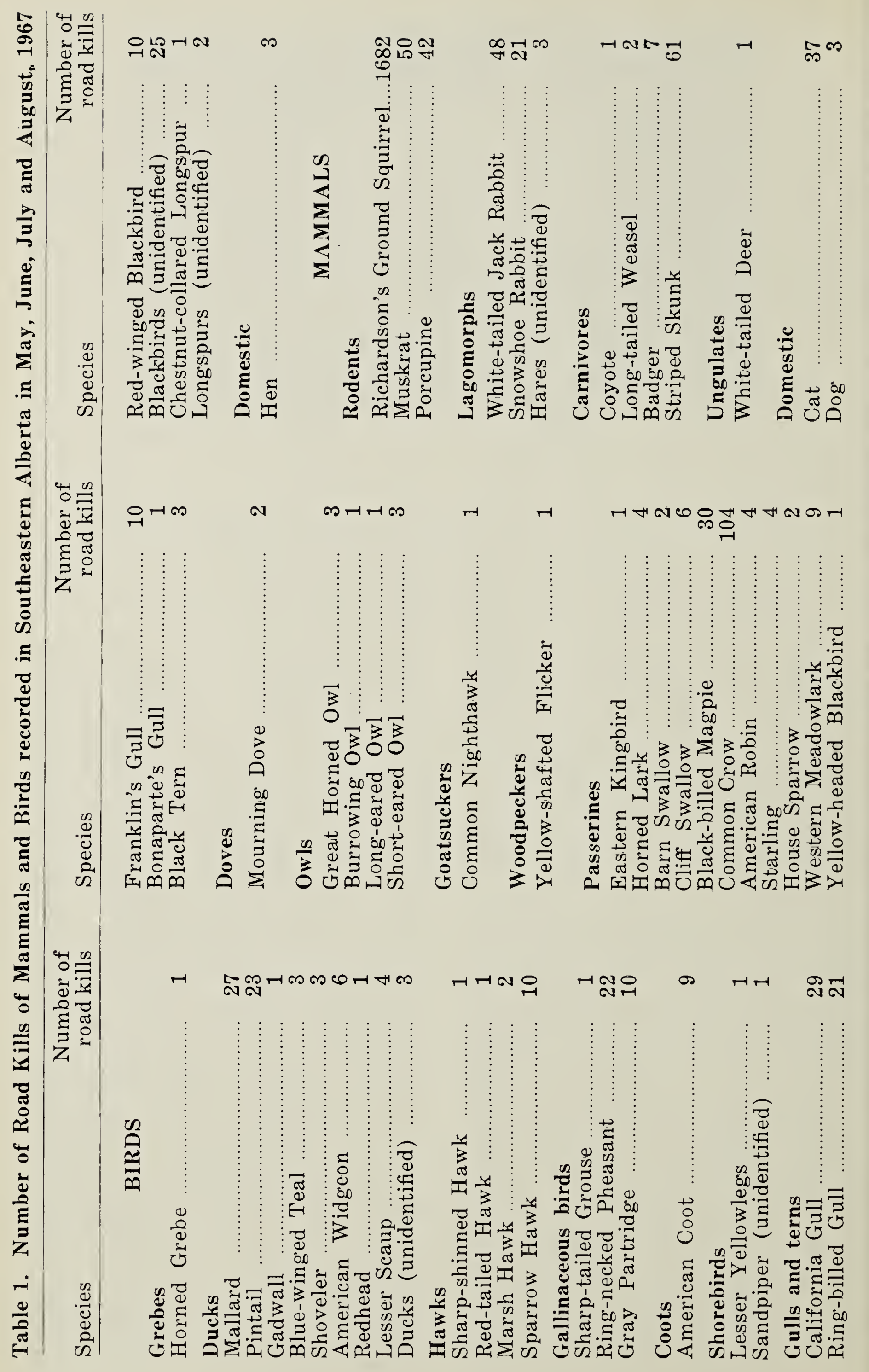

